\title{
HENDRIK STOKER AS MENS
}

Dis met gemengde gevoelens dat ek die versoek aanvaar het om iets te skryf na aanleiding van die feit dat prof. H. G. Stoker op 4 April 1964 sy vyfensestigste verjaarsdag gevier het: dankbaarheid om 'n mooi lewe van diens aan sy kerk, sy volk, die wetenskap; weemoed by die gedagte dat ook vir hom die tyd aangebreek het dat sy vaste verbintenis beëindig sal word met die Universiteit wat hy so trou en met die aanwending van sy buitengewone gawes gedien het oor 'n tydperk van veertig jaar.

My eerste herinneringe aan Hendrik Stoker gaan terug na een van die eerste, indien nie die eerste nie, jaarkongresse van die ou A.S.B. in die saal van die Oosteindskool, Pretoria, onder leiding van wyle Joon van Rooy. Dit was in 1916 of 1917. Ek het slegs 'n vlugtige beeld gekry van 'n blonde, effens skaamrige, geesdriftige en nog baie jeugdige student. Die tweede beeldjie is heelwat duideliker. Dit dateer uit die begin van die jare twintig. Ek was student in Amsterdam, en op 'n goeie dag daag Stoker by my op om 'n paar dae by my te kuier en iets te sien van die Nederlandse studentelewe. Onder andere wou ek hom kennis laat mak met die geneugtes van die Hollandse watersport en het ons op die destydse Schinkel gaan roei. Dit het nie so fortuinlik afgeloop nie. Teruyl ek agteroor op die agterpunt van die boot lê om 'n kiekie te neem van 'n Zeppelin wat soos 'n reusesigaar oor ons heen geseil het, doen my gas van opgewondenheid 'n paar slae met die roeispane, en daar lê ek met die kamera en korrel 'n paar meter onder die water! 'n Pak klere en 'n pragtig geblomde hemp van 'n boer het my op die koue dag in Mei gered van ernstige gevolge.

Hierdie insident was die begin van 'n samewerking en vriendskap wat tot vandag toe voortduur. Begin 1925 is ons albei aangestel as lektore aan die jong Potchefstroomse Universiteitskollege, gehuisves in die ou leërbarakke waarvoor die professore borg moes teken by die bank. Wyle professor $F$. Postma met sy kenmerkende ouderwets-stylvolle deftigheid was die besielende leier van die klein groepie dosente waarvan ons saam met die kort daarna aangestelde J. P. van der Merwe die jong-Turke was, waarby Stoker egter die voordeel gehad 
het dat hy student gewees het van oueres soos Totius, proff. Postma, J. C. van Rooy en J. C. Coetzee en mnr. L. J. du Plessis.

Die oorgang van die studentejare na 'n verantwoordelike betrekking is gewoonlik groot, maar dit was besonder groot vir ons toe ons ná jarelange afwesigheid in die buiteland skielik ons lewenstaak moes vind in die blikgeboue, sonder biblioteekgeriewe. Tog beskou ons dit as ' $n$ besondere voorreg dat ons die groei van ons inrigting kon meemaak vanaf so 'n nederige begin. En ek beskou dit as 'n voorreg dat ek hierdie periode kon deurmaak saam met Hendrik Stoker.

Ek het hom leer ken as 'n oop, eerlike karakter, met ' $n$ mooi, argelose vertroue in sy medemens, bereid om op gelyke voet met hom oor groot en klein dinge te diskusseer, en met 'n byna onbedwingbare neiging tot kwaaijongstreke wat hy selfs vandag nog nie heeltemal ontgroei het nie! Ons moes, om elkeen 'n slaap- en 'n studeerkamer te hê, saam 'n groot huis huur, waarin dit elke Dinsdagnag gespook het, iets wat dadelik die jong psigoloog se lewendige belangstelling gaande gemaak het, tot die bonatuurlike verskynsel in die laat ure van 'n donker nag gereduseer is tot die vier pote van 'n kalf op die holklinkende hoë hout vloer van die lang stoep om die huis!

Ek het ook die voorreg gehad om kennis te maak met die gesin Stoker, hulle gasvryheid te geniet in die gesellige huis in Johannesburg waar die tennisbaan die saamkomplek was van 'n groot vriendekring. Mnr. P. Stoker, 'n handelsman, was jare lank 'n gesiene lid van die Raad van ons inrigting. Saam met sy eggenote het hy sy liefde vir die P.U.K. ook betoon deur waardevolle geldskenkings. Daar het ek ook die twee begaafde jonger broers ontmoet wat later belangrike posisies sou beklee en die suster Jo wat kort daarna studente in Potchefstroom geword het.

Dis hier in Johannesburg dat die jong Hendrik onderrig gehad het op die Duitse skool voor hy aan die Potchefstroomse Gimnasium die matrikulasie-eksamen afgelê het, om daarna sy graad, die destydse O1-diploma en die Meestersgraad in die Wysbegeerte met lof aan die P.U.K. te behaal, voor hy aan die Universiteit van Keulen onder die beroemde fenomenoloog Max Scheler gepromoveer het op die voortreflike proefskrif „Das Gewissen".

Ek dink nog met weemoed terug aan menige laat aand dat ons ons verdiep het in die probleme van Christendom en 
wetenskap, lewensbeskouing en kuns, waarby die filosoof, met sy skerp wysgerige onderskeidinge, en die literator dit dikwels glad nie eens kan word nie. Maar ek het altyd die grootste waardering gehad vir Stoker se suiwer prinsipiële denke, sy beminlike gawe om altyd bereid te wees om, vry van vooringenomenheid en emosionaliteit, 'n ander se standpunt te respekteer en te oorweeg. En een van die grootste voldoeninge wat ek ooit gesmaak het, is toe dit baie jare later by geleentheid van 'n lesing oor Kuns en Lewensbeskouing wat ek gehou het voor die Universiteit se Filosofiese Vereniging, geblyk het dat ons in ons soeke uiteindelik baie ná aan mekaar te staan gekom het.

Dis m.i. aan hierdie skerp, deurtastende denke, gepaard aan die drang om rekening te hou met, sy voordeel te trek uit, die standpunt van ander, die resultate van so baie ander wetenskappe, dat Stoker se breë sintetiese siening as wysgeer te danke is, dat hy daarin geslaag het om by so baie andersdenkendes respek en erkenning af te dwing vir sy filosofie.

Sy aanvanklike breë leeropdrag: Wysbegeerte, Sielkunde en 'n tydlank ook Etiek, was 'n veeleisende taak wat harde werk geverg het maar 'n uitstekende voorbereiding was vir sy later toespits op suiwer filosofie. Die grootste bydrae wat hy tot die wetenskaplike vorming van die studente aan ons inrigting gelewer het, is ongetwyfeld die instelling op sy aandrang van die vir alle studente verpligte kursus „Beginsel- en Metodeleer", later verdoop tot „Studium Universale", waarvan die algemeen wysgerige deel nog steeds deur homself of onder sy leiding gedoseer word. Hy het hiermee 'n taak op hom geneem wat die afgelope decennium baie van sy tyd en kragte in beslag geneem en hom belemmer het in die verwesenliking van ander studie- en publikasieprojekte.

In die beraadslaginge van Senaat, komitees en fakulteite het Stoker hom 'n meelewende lid van die personeel betoon, ook as dekaan was hy 'n stukrag en het hy waardevolle leiding gegee.

Sy wetenskaplike prestasies is erken deur sy benoeming tot lid van die S.A. Akademie vir Wetenskap en Kuns, die toekenning deur hierdie liggaam van die Stalsprys, verskillende uitnodiginge om lesings op internasionale kongresse oorsee te hou en as uitruilprofessor aan die Vrye Universiteit van Amsterdam op te tree. Op vergaderinge van filosofiese kongresse in ons land speel hy 'n leidende rol. Hy was mede-op- 
rigter van die tydskrif Koers, waarvan hy 'n gereelde medewerker is, soos ook van Philosophia Reformata, waarvan hy sedert die oprigting mederedakteur is.

Hy het hom ook op breër nasionale gebied beweeg onder andere deur op groot volksfeeste op te tree as spreker wat aangespoor het tot prinsipiële besinning op ons roeping en op die probleme wat dit meebring. Sy leidende aandeel in die bedrywighede van die Ossewa-Brandwag en veral sy optrede teen die Liberalisme, o.a. in sy bekende „Die Stryd om die Ordes", het hom tydens die troebelinge van die oorlogsjare internering op Koffiefontein en later plaasarres gekos maar nie sy geesdrif, optimisme en humorsin beneem nie.

Stoker het ook sy kerk gedien as ouderling en as afgevaardigde na die eerste Ekumeniese Sinode van die Gereformeerde Kerke in Grand Rapids, V.S.A. Op hierdie reis het hy ook bekendheid verwerf in Amerika met 'n reeks lesings, o.a. voor die Derde Amerikaanse Calvinistiese Kongres.

Saam met die indrukwekkende lys wetenskaplike publikasies, waarin hy as oorspronklike denker riglyne van 'n eie filosofie gegee het, bied hierdie vlugtige oorsig die beeld van 'n lewe gewy aan die nastreef van die verwesenliking van sy wetenskaplike, nasionale en godsdienstige oortuigings.

Stoker smaak die groot voorreg dat sy twee seuns in hulle vader se wetenskaplike voetspore, sy dit op heeltemal ander terreine, volg.

Mag dit hom beskore wees om nog geruime tyd nie alleen deur sy geskrifte nie maar ook as dosent sy besielende invloed te laat geld op ons studerende jeug, soos hy dit veertig jaar lank gedoen het - studerendes in allerlei rigtinge, veral ook tcoloë, kan daarvan getuig. En mag hy daarin by voortduring gesteun word deur sy opgewekte eggenote, wat deur haar optimisme en praktiese sin vir hom steeds 'n inspirasie was.

Dit is die bede van diegene wat die beskeie, teruggetrokke mens Hendrik Stoker ken nie alleen as kamergeleerde nie maar ook as lojale vriend wat vreugde en smart, ook die klein, intieme dinge van die lewe in opregtheid en eenvoud met ander kan deel.

Potchefstroom.

G. Dekker. 